\title{
Effects of Applying Accumulator Straw in Cd-Contaminated Soil on Nutrient Uptake of Galinsoga parviflora
}

\author{
Jin Wang ${ }^{1, a}$, Jun Shi ${ }^{2, b}$, Shuting Yang ${ }^{1, c}$ and Xiulan $L v^{3, d *}$ \\ ${ }^{1}$ College of Horticulture, Sichuan Agricultural University, Chengdu, Sichuan, China \\ ${ }^{2}$ Mianyang Academy of Agricultural Sciences, Mianyang, Sichuan, China \\ ${ }^{3}$ Institute of Pomology and Olericulture, Sichuan Agricultural University, Chengdu, Sichuan, China

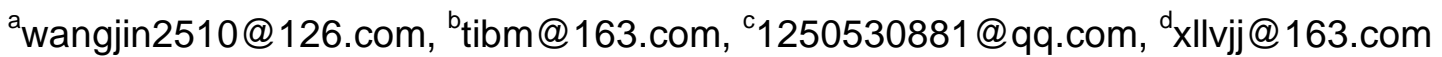 \\ ${ }^{*}$ Corresponding author
}

Keywords: Accumulator straw; Cadmium contamination; Galinsoga parviflora; Nutrient uptake Abstract. The effects of applying four accumulator species (Conyza canadensis, Cardamine hirsute, Eclipta prostrate and Nasturtium officinale) straws in cadmium (Cd) contaminated soil on phosphorus $(\mathrm{P})$, potassium $(\mathrm{K})$ and nitrogen $(\mathrm{N})$ uptakes of Galinsoga parviflora were studied through the pot experiment. Five treatments were used in the experiment: control (no straw applied), and straw applied for each of the four plant species (C. canadensis, $C$. hirsute, E. prostrata and $N$. officinale). When applying the four accumulator species straws in Cd-contaminated soil, only $E$. prostrata straw and $N$. officinale straw increased the total $\mathrm{P}$ and $\mathrm{K}$ contents in roots, stems and leaves of G. parviflora compared with control, and $E$. prostrata straw was the best. Only applying straws of $C$. canadensis, $C$. hirsute and $N$. officinale increased the total $\mathrm{N}$ content in stems and leaves of G. parviflora compared with control, and the rank was $C$. canadensis straw $>N$. officinale straw $>C$. hirsuta straw $>$ control. Therefore, only suitable applying accumulator straw could used to increase nutrient uptake of $G$. parviflora in Cd-contaminated soil.

\section{Introduction}

Applying the crop straw into soil can increase nutrient such as phosphorus (P), potassium (K) and nitrogen $(\mathrm{N})$ in soil [1]. However, some studies show that the straws of wheat, corn, soybean and bean inhibit the growth of these crop species seedlings [2]. Therefore, if we apply cadmium $(\mathrm{Cd})$ accumulator straw into soil, and plant hyperaccumulator, the nutrient uptake of hyperaccumulator could be enhanced. Conyza canadensis [3], Cardamine hirsute [4], Eclipta prostrate [5] and Nasturtium officinale [6] are Cd-accumulator plants. In this paper, we applied the straw made from the shoots of $C$. canadensis, $C$. hirsute, E. prostrate and $N$. officinale into Cd-contaminated soil and planted the Cd-hyperaccumulator plant Galinsoga parviflora [7]. The aim of the study was to determine if application of straw from the accumulator species could efficiently promote the nutrient uptake and growth of G. parviflora.

\section{Materials and Methods}

Materials. In August 2013, the shoots of C. canadensis, C. hirsute, E. prostrate and N. officinale were collected from the Ya'an campus farm of Sichuan Agricultural University $\left(29^{\circ} 59^{\prime} \mathrm{N}, 102^{\circ} 59^{\prime} \mathrm{E}\right)$, China, from uncontaminated soil areas. The collected shoots of these plants were dried at $80{ }^{\circ} \mathrm{C}$ to constant weight, finely ground and sieved through a 5-mm-mesh nylon sieve. Galinsoga parviflora seedlings with two pairs of euphyllas were collected from the Ya'an campus farm (from uncontaminated soil) in September 2013. The inceptisol soil samples were collected from Ya'an campus farm in August 2013. The basic properties of the soil were the same as reference [7].

Experimental Design. The experiment was conducted at the Ya'an campus farm from August to October in 2013. The soil samples were air-dried and passed through a 5-mm sieve. Three kilograms of the air-dried soil was weighed into each polyethylene pot (15 cm high, $18 \mathrm{~cm}$ in diameter). Cd was 
added to soils as $\mathrm{CdCl}_{2} \cdot 2.5 \mathrm{H}_{2} \mathrm{O}$ at $40 \mathrm{mg} / \mathrm{kg}$ [8-9]. The pots were soaked in the Cd solutions for 4 weeks, and then the soil in each pot was mixed with the powdered shoots of the studied plants. Six-gram shoots were applied to each pot ( 2 g shoots per $\mathrm{kg}$ soil [8-9]), and the soil moisture was maintained at $80 \%$ of field capacity for 1 week. The five experimental treatments in the experiment were control (no straw applied), and straw applied for each of the four plant species (C. canadensis, $C$. hirsute, E. prostrate and N. officinale). Each treatment was replicated three times using a completely randomized design with $10-\mathrm{cm}$ spacing between pots. Four uniform seedlings of G. parviflora were transplanted into each pot and the soil moisture content was maintained at $80 \%$ of field capacity from the time the plants were transplanted into the pots until the time the plants were harvested. At maturity (after $50 \mathrm{~d}$ ), the entire plants were harvested for determining contents of total $\mathrm{P}, \mathrm{K}$ and $\mathrm{N}$ in roots, stems and leaves [10]. The soil samples were collected for determining soil available $\mathrm{P}$ and $\mathrm{K}$ contents [10].

\section{Results and Discussion}

Total $\mathbf{P}$ content in $G$. parviflora. When applying the four accumulator species straws in Cd-contaminated soil, the total P contents in roots and stems of $G$. parviflora were ranked as: $E$. prostrata straw $>N$. officinale straw $>$ control $>C$. hirsuta straw $>C$. canadensis straw (Table 1). Compared with control, applying straws of $C$. canadensis and $C$. hirsute in soil decreased the total $\mathrm{P}$ contents in roots of $G$. parviflora by $14.92 \%(p<0.05)$ and $5.65 \%(p>0.05)$ respectively, decreased by $14.33 \%(p<0.05)$ and $14.66 \%(p<0.05)$ in stems respectively. Applying straws of E. prostrate and N. officinale increased the total P contents in roots of $G$. parviflora by $13.71 \%(p<0.05)$ and $2.42 \%$ $(p>0.05)$ respectively, increased by $5.86 \%(p>0.05)$ and $1.63 \%(p>0.05)$ in stems respectively compared with control. The total $\mathrm{P}$ content in leaves of $G$. parviflora was ranked as: E. prostrata straw $>N$. officinale straw $>$ control $>C$. hirsuta straw $>C$. canadensis straw (Table 1). Applying straws of $C$. canadensis and $C$. hirsute in soil decreased the total P contents in leaves of G. parviflora by $15.12 \%(p<0.05)$ and $5.56 \%(p<0.05)$ respectively, and applying straws of $E$. prostrate and $N$. officinale increased the total P contents in leaves of G. parviflora by $6.79 \%(p<0.05)$ and $1.85 \%(p>$ 0.05 ) respectively compared with control.

Table 1 Total P content in G. parviflora

\begin{tabular}{|l|l|l|l|}
\hline Treatments & Roots $(\mathrm{g} / \mathrm{kg})$ & Stems $(\mathrm{g} / \mathrm{kg})$ & Leaves $(\mathrm{g} / \mathrm{kg})$ \\
\hline Control & $2.48 \pm 0.116 \mathrm{bc}$ & $3.07 \pm 0.087 \mathrm{a}$ & $3.24 \pm 0.022 \mathrm{~b}$ \\
\hline C. canadensis & $2.11 \pm 0.038 \mathrm{~d}$ & $2.63 \pm 0.108 \mathrm{~b}$ & $2.75 \pm 0.104 \mathrm{~d}$ \\
\hline C. hirsuta & $2.34 \pm 0.014 \mathrm{c}$ & $2.62 \pm 0.027 \mathrm{~b}$ & $3.06 \pm 0.003 \mathrm{c}$ \\
\hline E. prostrata & $2.82 \pm 0.031 \mathrm{a}$ & $3.25 \pm 0.082 \mathrm{a}$ & $3.46 \pm 0.033 \mathrm{a}$ \\
\hline N. officinale & $2.54 \pm 0.008 \mathrm{~b}$ & $3.12 \pm 0.024 \mathrm{a}$ & $3.30 \pm 0.020 \mathrm{~b}$ \\
\hline
\end{tabular}

Values are means of three replicate pots. Different lowercase letters indicate significant differences based on one-way analysis of variance in SPSS 13.0 followed by the least significant difference test $(p<0.05)$.

Total $\mathrm{K}$ content in $G$. parviflora. The same as total $\mathrm{P}$ content in plants, the total K contents in roots, stems and leaves of G. parviflora were also ranked as: E. prostrata straw $>N$. officinale straw > control $>C$. canadensis straw $>C$. hirsuta straw (Table 2). Applying straws of E. prostrate and $N$. officinale increased the total $\mathrm{K}$ content in roots of G. parviflora by $7.55 \%(p>0.05)$ and $5.22 \%(p>$ $0.05)$ respectively compared with control. Compared with control, the total K content in stems of $G$. parviflora was increased by 5.88\% $(p>0.05)$ and $5.03 \%(p>0.05)$ of E. prostrata straw and $N$. officinale straw respectively, and increased total K content in leaves by $9.39 \%(p>0.05)$ and $5.03 \%$ $(p>0.05)$ of that respectively. So, only applying accumulator straw of E. prostrata and $N$. officinale could enhance the $\mathrm{P}$ and $\mathrm{K}$ uptakes of $\mathrm{G}$. parviflora from Cd-contaminated soil. 
Table 2 Total K content in G. parviflora

\begin{tabular}{|l|l|l|l|}
\hline Treatments & Roots $(\mathrm{g} / \mathrm{kg})$ & Stems $(\mathrm{g} / \mathrm{kg})$ & Leaves $(\mathrm{g} / \mathrm{kg})$ \\
\hline Control & $7.28 \pm 0.028 \mathrm{~b}$ & $4.76 \pm 0.057 \mathrm{~b}$ & $7.56 \pm 0.071 \mathrm{c}$ \\
\hline C. canadensis & $6.95 \pm 0.071 \mathrm{c}$ & $4.43 \pm 0.042 \mathrm{c}$ & $6.68 \pm 0.113 \mathrm{e}$ \\
\hline C. hirsuta & $7.13 \pm 0.099 \mathrm{bc}$ & $4.57 \pm 0.099 \mathrm{c}$ & $7.04 \pm 0.085 \mathrm{~d}$ \\
\hline E. prostrata & $7.83 \pm 0.042 \mathrm{a}$ & $5.04 \pm 0.049 \mathrm{a}$ & $8.27 \pm 0.099 \mathrm{a}$ \\
\hline N. officinale & $7.66 \pm 0.085 \mathrm{a}$ & $4.89 \pm 0.085 \mathrm{ab}$ & $7.94 \pm 0.106 \mathrm{~b}$ \\
\hline
\end{tabular}

Values are means of three replicate pots. Different lowercase letters indicate significant differences based on one-way analysis of variance in SPSS 13.0 followed by the least significant difference test $(p<0.05)$.

Total $\mathbf{N}$ content in $\boldsymbol{G}$. parviflora. When applying the four accumulator species straws in Cd-contaminated soil, the total $\mathrm{N}$ content in roots of $G$. parviflora decreased, and ranked control $>C$. hirsuta straw $>C$. canadensis straw $>$ E. prostrata straw $>N$. officinale straw (Table 3). Compared with control, applying straws of $C$. canadensis, $C$. hirsute, E. prostrata and $N$. officinale in soil decreased the total N contents in roots of G. parviflora by $23.91 \%(p<0.05), 9.35 \%(p<0.05)$, $26.30 \%(p<0.05)$ and $28.48 \%(p<0.05)$ respectively. The total N contents in stems and leaves of $G$. parviflora were ranked as: $C$. canadensis straw $>N$. officinale straw $>C$. hirsuta straw $>$ control $>E$. prostrata straw. Applying straws of $C$. canadensis, $C$. hirsute and $N$. officinale increased the total $\mathrm{N}$ contents in stems of $G$. parviflora by $15.51 \%(p<0.05), 7.24 \%(p>0.05)$ and $10.81 \%(p>0.05)$ respectively, increased by $21.88 \%(p<0.05), 0.43 \%(p>0.05)$ and $6.92 \%(p>0.05)$ in stems respectively compared with control.

Table 3 Total N content in G. parviflora

\begin{tabular}{|l|l|l|l|}
\hline \multicolumn{1}{|c|}{ Treatments } & Roots $(\mathrm{g} / \mathrm{kg})$ & Stems $(\mathrm{g} / \mathrm{kg})$ & Leaves $(\mathrm{g} / \mathrm{kg})$ \\
\hline Control & $9.20 \pm 0.16 \mathrm{a}$ & $10.64 \pm 0.91 \mathrm{~b}$ & $16.32 \pm 0.45 \mathrm{~b}$ \\
\hline C. canadensis & $7.00 \pm 0.28 \mathrm{c}$ & $12.29 \pm 0.41 \mathrm{a}$ & $19.89 \pm 0.83 \mathrm{a}$ \\
\hline C. hirsuta & $8.34 \pm 0.06 \mathrm{~b}$ & $11.41 \pm 0.58 \mathrm{ab}$ & $16.39 \pm 0.86 \mathrm{~b}$ \\
\hline E. prostrata & $6.78 \pm 0.11 \mathrm{~cd}$ & $7.74 \pm 0.34 \mathrm{c}$ & $14.36 \pm 0.51 \mathrm{c}$ \\
\hline N. officinale & $6.58 \pm 0.07 \mathrm{~d}$ & $11.79 \pm 0.30 \mathrm{ab}$ & $17.45 \pm 0.64 \mathrm{~b}$ \\
\hline
\end{tabular}

Values are means of three replicate pots. Different lowercase letters indicate significant differences based on one-way analysis of variance in SPSS 13.0 followed by the least significant difference test $(p<0.05)$.

Soil available $\mathbf{P}$ content. When applying the four accumulator species straws in Cd-contaminated soil, only the straws of E. prostrata and $N$. officinale increased the soil available P content compared with control (Table 4). The soil available P content was ranked as: E. prostrata straw $>N$. officinale straw $>$ control $>C$. hirsuta straw $>C$. canadensis straw. Compared with control, applying $C$. canadensis straw and $C$. hirsuta straw decreased the soil available $\mathrm{P}$ content by $4.47 \%(p>0.05)$ and $1.40 \%(p>0.05)$ respectively, and E. prostrata straw and $N$. officinale straw increased $16.48 \%(p<$ $0.05)$ and $11.17 \%(p<0.05)$ respectively.

Soil available $\mathrm{K}$ content. The same as the soil available $\mathrm{P}$ content, the soil available $\mathrm{K}$ content decreased compared with control when applying $C$. canadensis straw and $C$. hirsuta straw in Cd-contaminated soil, and E. prostrata straw and $N$. officinale straw increased the soil available $\mathrm{K}$ content (Table 4). The soil available K content was also ranked as: E. prostrata straw $>N$. officinale straw $>$ control $>C$. hirsuta straw $>C$. canadensis straw.

Alkali soluble $\mathbf{N}$ content. Except applying E. prostrata straw decreased alkali soluble N content, $C$. canadensis straw, $C$. hirsuta straw and $N$. officinale straw increased alkali soluble N content compared 
with control (Table 4). The alkali soluble $\mathrm{N}$ content was ranked as: $C$. canadensis straw $>N$. officinale straw $>C$. hirsuta straw $>$ control $>$ E. prostrata straw.

Table 4 Soil available nutrient concentration

\begin{tabular}{|l|c|c|c|}
\hline \multicolumn{1}{|c|}{ Treatments } & $\begin{array}{c}\text { Soil available phosphorus } \\
(\mathrm{mg} / \mathrm{kg})\end{array}$ & $\begin{array}{c}\text { Soil available potassium } \\
(\mathrm{mg} / \mathrm{kg})\end{array}$ & $\begin{array}{c}\text { Alkali soluble nitrogen } \\
(\mathrm{mg} / \mathrm{kg})\end{array}$ \\
\hline Control & $3.58 \pm 0.134 \mathrm{~b}$ & $120.32 \pm 1.87 \mathrm{ab}$ & $124.63 \pm 3.98 \mathrm{c}$ \\
\hline C. canadensis & $3.42 \pm 0.164 \mathrm{~b}$ & $115.41 \pm 1.99 \mathrm{~b}$ & $165.21 \pm 0.45 \mathrm{a}$ \\
\hline C. hirsuta & $3.53 \pm 0.039 \mathrm{~b}$ & $118.92 \pm 2.72 \mathrm{~b}$ & $136.81 \pm 1.42 \mathrm{~b}$ \\
\hline E. prostrata & $4.17 \pm 0.025 \mathrm{a}$ & $125.85 \pm 2.62 \mathrm{a}$ & $122.74 \pm 2.39 \mathrm{c}$ \\
\hline N. officinale & $3.98 \pm 0.187 \mathrm{a}$ & $121.37 \pm 1.94 \mathrm{ab}$ & $143.24 \pm 4.29 \mathrm{~b}$ \\
\hline
\end{tabular}

Values are means of three replicate pots. Different lowercase letters indicate significant differences based on one-way analysis of variance in SPSS 13.0 followed by the least significant difference test $(p<0.05)$.

\section{Conclusions}

When applying the four accumulator species (C. canadensis, C. hirsuta, E. prostrata and N. officinale) straws in Cd-contaminated soil, only E. prostrata straw and $N$. officinale straw increased the total $\mathrm{P}$ and $\mathrm{K}$ contents in roots, stems and leaves of G. parviflora compared with control, and E. prostrata straw was the best. Only applying straws of $C$. canadensis, $C$. hirsute and $N$. officinale increased the total $\mathrm{N}$ content in stems and leaves of $G$. parviflora compared with control, and the rank was $C$. canadensis straw $>N$. officinale straw $>C$. hirsuta straw $>$ control. Therefore, only suitable applying accumulator straw could used to increase nutrient uptake of G. parviflora in Cd-contaminated soil.

\section{References}

[1] J. Wu, Z.L. Zhu, J.G. Zheng and X.L. Jiang: Southwest China Journal of Agricultural Sciences Vol. 19 (2006), p. 192.

[2] S.C. Yang, L. Huo and J.C. Wang: Acta Agriculturae Boreali-Occidentalis Sinica Vol. 14 (2005), p. 52.

[3] S. Wei, Q. Zhou, U.K. Saha, H. Xiao, Y. Hu, L.P. Ren and P. Gu: Journal of Hazardous Materials Vol. 163 (2009), p. 32.

[4] L. Lin, J. Shi, Q. Liu, M. Liao and L. Mei: Environmental Monitoring and Assessment Vol. 186 (2014), p. 4051.

[5] L. Luo, L.J. Lin, M.A. Liao, X. Zhang and D.Y. Yang: Acta Agriculturae Boreali-Sinica Vol. 29 (2014), p. 216.

[6] L.J. Lin, L. Luo, M.A. Liao, X. Zhang and D.Y. Yang: Resources and Environment in the Yangtze Basin Vol. 24 (2015), p. 684.

[7] L. Lin, Q. Jin, Y. Liu, B. Ning, M. Liao and L. Luo: Environ. Toxicol. Chem. Vol. 33 (2014), p. 2422.

[8] L.J. Lin, D.Y. Yang, F.Y. Tang, L. Luo, M.A. Liao, and L. Yuan: Chinese Journal of Soil Science Vol. 46 (2015), p. 483.

[9] L. Lin, M. Liao, Y. Ren, L. Luo, X. Zhang, D. Yang and J. He: PLoS ONE Vol. 9 (2014), p. e114957.

[10]S.D. Bao: Agrochemical Soil Analysis ( $3^{\text {rd }}$ edition, China Agriculture Press, Beijing 2000). 